\title{
EFEKTIVITAS PENGEMBANGAN PERANGKAT PEMBELAJARAN \\ BERBASIS PENDEKATAN KONTEKSTUAL \\ PADA MATERI MENULIS RESENSI SISWA \\ SMA 1 LENGAYANG
}

\author{
Atika Gusriani $^{1}$, Zherry Putria Yanti $^{2}$ \\ E-mail : gusrianiatika@gmail.com ${ }^{1}$, zherryputriayanti@gmail.com ${ }^{2}$
}

\begin{abstract}
Abstrak
Perangkat pembelajaran yang digunakan belum mampu menjawab kebutuhan siswa guna tercapainya tujuan pembelajaran. Tujuan penelitian ini adalah menjelaskan proses pengembangan perangkat pembelajaran bahasa Indonesia berbasis pendekatan kontekstual yang efektif pada materi menulis resensi siswa SMA 1 Lengayang. Jenis penelitian ini adalah penelitian pengembangan. Penelitian ini menggunakan model 4-D yang terdiri atas empat tahap, yaitu tahap pendefinisian (define), perancangan (design), pengembangan (develop), dan penyebaran (disseminate). Hasil penelitian menunjukkan bahwa perangkat pembelajaran berbasis pendekatan kontekstual untuk pembelajaran menulis resensi siswa SMA 1 Lengayang yang dikembangkan efektif. Hal tersebut berdasarkan hasil efektivitas perangkat pembelajaran yang terdiri atas hasil belajar siswa memiliki rata-rata sebesar 85,51 dengan kualifikasi baik dan aktivitas siswa yang memiliki ketercapaian sebesar 76,19 dengan kriteria sangat tinggi.
\end{abstract}

Kata Kunci: pengembangan, perangkat pembelajaran, kontekstual, menulis, resensi

\section{PENDAHULUAN}

Menulis resensi merupakan kegiatan menuangkan ide dan gagasan ke dalam bntuk tulisan. Tulisan tersebut berisis ulasan dan komentar terhadap sebuah buku. Menurut Ramadansyah (2010:160), resensi merupakan suatu tulisan atau ulasan mengenai nilai hasil karya yang sifatnya baru untuk dipertimbangkan pembaca/penikmat. Tujuan penyampaiannya adalah apakah sebuah buku patut atau tidak mendapat sambutan atau tidak.

Berdasarkan pengamatan peneliti di SMA negeri 1 Lengayang, terdapat beberapa permasalahan pembelajaran menulis resensi. Permasalahan tersebut berasal dari siswa dan guru. Permasalahan yang berasal dari siswa antara lain sebagai berikut. Siswa tidak memiliki keinginan dan acuh tak acuh terhadap tulisan yang ingin dijadikan sumber resensi. Hal ini dapat dilihat pada saat proses pembelajaran berlangsung di kelas. Banyak siswa yang pasif dan tidak bersemangat dalam mengikuti pelajaran. Hal lain juga dapat dilihat dari hasil 
lembaran tulisan kerja siswa. Di sana terlihat, siswa belum mampu menuliskan tentang sistematika penulisan resensi yang tepat. Siswa juga belum dapat mengungkapkan ide/gagasannya dengan menggunakan kalimat sendiri secara tepat.

Guru di dalam proses pembelajaran melakukan metode ceramah demi mengejar ketercapaian materi tanpa mempertimbangkan apakah siswa sudah mengerti atau tidak. Siswa tidak diberikan kesempatan untuk memberikan tanggapan serta pendapat tentang pembelajaran yang sedang berlangsung. Keterbatasan bahan ajar juga semakin memperburuk proses pembelajaran di dalam kelas. Guru sebagai fasilitator seharusnya dapat mengembangkan perangkat pembelajaran seperti, silabus, RPP, LKS, bahan ajar, dan penilaian agar materi pelajaran mudah dipahami oleh siswa dan hasil belajar siswa dapat diperoleh dengan maksimal.

Salah satu cara agar pemahaman tentang menulis resensi dapat dipahami adalah dengan menggunakan pembelajaran berbasis pendekatan kontekstual. Berkaitan dengan hal itu, guru dihadapkan pada tantangan dan masalah bagaimana mencari cara yang terbaik untuk menyampaikan konsep-konsep yang mereka ajarkansedemikian rupa tepatnya agar semua siswa dapat menggunakan dan menyimpan informasi tersebut.

Perangkat pembelajaran berbasis pendekatan kontekstual merupakan salah satu alternatif untuk memecahkan permasalahan di dalam menulis resensi siswa tersebut. Perangkat pembelajaran seperti silabus, RPP, bahan ajar berupa handout, LKS, dan penilaian adalah penunjang pembelajaran yang dapat dimanfaatkan oleh guru di kelas. Dengan perencanaan silabus dan RPP yang matang, guru diharapkan dapat menjalankan proses pembelajaran seefektif mungkin. Begitu juga dengan LKS yang telah dirancang sesuai dengan materi pelajaran. Siswa dapat lebih mudah memahami latihan-latihan yang terdapat pada lembar kerja siswa tersebut. Selanjutnya, dengan bantuan bahan ajar berupa handout yang dirancang berbasis pendekatan kontekstual, lebih memudahkan siswa dalam mendalami setiap materi ajar yang ingin dipahami. Penilaian pun dirancang dengan menyesuaikan indikator yang telah ditetapkan sehingga guru dan siswa dapat memperoleh hasil belajar yang ingin dicapai dengan tuntutan standar kompetensi dan kompetensi dasar yang telah ditetapkan.

Pengembangan perangkat pembelajaran berbasis pendekatan kontekstual dapat meningkatkan keefektivan dalam pembelajaran. Hal ini sejalan dengan penelitian yang dilakukan Badariah (2010), menyimpulkan bahwa perangkat pembelajaran dikategorikan rata-rata valid. Nilai praktikalitas berdasarkan pengamatan keterlaksanaan RPP serta respons guru dan siswa di SMAN 5 Jambi dan SMAN 8 Jambi dalam kategori baik dengan 
ketuntasan klasikal di atas $90 \%$. Untuk hasil belajar ranah afektif dan psikomotor termasuk dalam kategori baik. Jadi perangkat pembelajaran kimia SMA berorientasi pendekatan CTL yang dikembangkan sudah valid, praktis, dan efektif pada kompetensi dasar memahami sistem dan sifat koloid serta penerapannya dalam kehidupan sehari-hari.

Selain itu, hasil penelitian Yolanda (2010) menunjukkan bahwa rata-rata validitas media komik adalah 2,9 dengan kategori valid. Hasil uji praktikalitas oleh siswa menunjukkan rata-rata 78,96\% dengan kategori praktis. Uji evektifitas menunjukkan bahwa $64,53 \%$ siswa aktif dalam belajar dengan media komik dan memiliki hasil belajar tuntas dengan ketuntasan siswa 21 dari 40 siswa. Dari hasil penelitian bahwa komik berbasis CTL pada materi bangun datar yang dikembangkan telah valid, praktis, dan efektif digunakan sebagai media pembelajaran untuk kelas III sekolah dasar.

\section{KAJIAN TEORI}

\section{Pengertian Menulis Resensi}

Resensi adalah pertimbangan atau ulasan tentang sebuah buku dengan tujuan untuk memberitahu kepada pembaca perihal buku-buku baru dan ulasan kelebihan maupun kekurangan buku tersebut. Resensi bertujuan untuk menyampaikan kepada pembaca apakah sebuah buku atau hasil karya itu patut mendapat sambutan dari masyarakat atau tidak. Bertolak dari tujuannya, resensi bermanfaat bagi pembaca untuk menentukan perlu tidaknya membaca buku tertentu atau perlu tidaknya menikmati suatu hasil karya seni, dikutip oleh Aleka dan H. Achmad, (2010:132).

Selanjutnya Rahardi (2010:178), menambahkan bahwa resensi umumnya dipahami sebagai ulasan dan penilaian terhadap sebuah karya. Karya tersebut dapat bermacam-macam, mungkin film, mungkin buku, mungkin karya seni, atau mungkin pula sebuah produk teknologi. Penilaian itu harus berkaitan dengan kualitas dari karya yang sedang dicermati atau diresensi.

\section{Pembelajaran Berbasis Pendekatan Kontekstual (CTL)}

Menurut Johnson (2007:88), CTL membantu para siswa menemukan makna dalam pelajaran mereka dengan cara menghubungkan materi akademik dengan konteks kehidupan keseharian mereka. Mereka membuat hubungan-hubungan penting yang menghasilkan makna dengan melaksanakan pembelajaran yang diatur sendiri, bekerja sama, berpikir kritis dan kreatif, menghargai orang lain, mencapai standar tinggi, dan berperan serta dalam tugastugas penilaian autentik. 
Trianto (2009:107) menambahkan bahwa, pembelajaran berbasis kontekstual dapat dikatakan sebagai sebuah pendekatan pembelajaran yang mengakui dan menunjukkan kondisi alamiah dari pengetahuan. Melalui hubungan di dalam dan di luar kelas, suatu pendekatan pembelajaran kontekstual menjadikan pengalaman lebih relevan dan berarti bagi siswa dalam membangun pengetahuan yang akan mereka terapkan dalam pembelajaran seumur hidup. Pembelajaran kontekstual menyajikan suatu konsep yang mengaitkan materi pelajaran yang dipelajari siswa dengan konteks di mana materi tersebut digunakan, serta berhubungan dengan bagaimana seseorang belajar atau gaya/cara siswa belajar.

\section{Pengembangan Perangkat Pembelajaran}

Pengembangan perangkat pembelajaran adalah serangkaian proses atau kegiatan yang dilakukan untuk menghasilkan suatu perangkat pembelajaran berdasarkan teori pengembangan yang ada, dikutip oleh Rohman (2013:207). Pengembangan perangkat pembelajaran merupakan pengembangan yang bertujuan untuk mendapatkan prototipe produk dan perumusan saran-saran metodologis untuk pendesainan dan evaluasi prototipe tersebut. Proses dan produk di dalam pengembangan perangkat pembelajaran harus memenuhi kriteria validitas, praktikalitas, dan efektivitas.

Pengembangan perangkat pembelajaran didasarkan pada konsep-konsep yang bisa dijadikan sebagai pemecah dalam masalah pembelajaran. Demikian juga dengan pengembangan perangkat pembelajaran yang bisa digunakan dalam mencapai tujuan pembelajaran oleh guru dan siswa.

\section{Kriteria Perangkat Pembelajaran yang Efektif}

Menurut Rohman (2013:207), perangkat pembelajaran dikatakan efektif apabila produk memberikan hasil sesuai dengan tujuan yang telah ditetapkan oleh pengembang. Sejalan dengan pendapat Fauzan (2002) bahwa keefektifan perangkat pembelajaran tercapai bila terdapat konsisten antara tipologi harapan dan pengalaman, serta tipologi harapan dan perolehan.

Dengan demikian dapat disimpulkan bahwa ada tiga kriteria yang harus dipenuhi oleh perangkat pembelajaran yang dikembangkan. Yakni kriteria valid, praktis, dan efektif. Aspek validitas dikaitkan dengan dua hal, yaitu (1) apakah kurikulum atau strategi yang dikembangkan berdasarkan rasional teoritik yang kuat? Dan (2) apakah terdapat konsistensi secara internal?

Aspek kepraktisan dipenuhi jika, (1) ahli dari praktisi menyatakan bahwa apa yang dikembangkan dapat diterapkan, dan (2) kenyataan menunjukkan bahwa apa yang 
dikembangkan memang dapat diterapkan. Untuk aspek efektivitas, ada dua indikator yakni, (1) ahli praktisi berdasarkan pengalaman mengatakan strategi tersebut efektif, dan (2) dalam operasionalnya strategi pembelajaran terlaksana dengan efektif dan diperolehnya hasil belajar yang memuaskan.

\section{METODE PENELITIAN}

Model pengembangan yang digunakan oleh peneliti adalah model pengembangan 4-D (four D). Model ini merupakan model pengembangan perangkat pembelajaran yang dikembangkan oleh S. Thiagarajan, Dorothy, S., dan Semmel dalam Trianto (2012:93). Model pengembangan 4-D terdiri atas empat tahap utama yaitu (1) pendefinisian (define), (2) perancangan (design), (3) pengembangan (develop), dan (4) penyebaran (disseminate). Namun, penelitian ini hanyasampai pada tahap pengembangan. Sedangkan tahap penyebaran tidak dilakukan.

Subjek uji coba dalam penelitian pengembangan ini adalah siswa kelas XI IA.1 SMA negeri 1 Lengayang Pesisir Selatan tahun ajaran 2013/2014, dengan jumlah siswa 35 orang. Uji coba dilakukan untuk mengetahui efektivitas perangkat pembelajaran yang dikembangkan.

Uji keefektifan perangkat pembelajaran dilakukan dengan melihat nilai hasil belajar dan aktivitas siswa selama pembelajaran. Untuk menilai hasil belajar siswa, dapat dilakukan dengan mengadakan evaluasi. Pemberian tes atau evaluasi dilakukan di akhir proses pembelajaran dengan tujuan untuk mengetahui hasil pembelajaran menulis resensi.

Uji efektivitas meliputi aktivitas dan hasil belajar siswa. Selama kegiatan pembelajaran berlangsung, pembelajaran diamati oleh pengamat atau observer. Tujuan pengamatan ini adalah unutuk mengamati aktivitas siswa terhadap kegiatan pembelajaran. Pengamat pada penelitian ini adalah guru mata pelajaran Bahasa Indonesia SMA Negeri 1 Lengayang dan peneliti sendiri. Uji efektivitas dilakukan dengan mengamati siswa selama proses pembelajaran dan mengisi lembar aktivitas siswa. Kemudian uji efektivitas ini juga diperoleh dari pengamatan tes hasil belajar menulis resensi oleh siswa.

Pada dasarnya efektivitas tersebut diukur dengan cara melihat ada atau tidaknya efek atau pengaruh produk yang dikembangkan terhadap pengguna produk atau hasil belajar siswa. Pada tahap ini akan dilakukan evaluasi untuk mengetahi apakah perangkat pembelajaran yang dirancang efektif untuk memicu aktivitas positif yang dapat meningkatkan 
hasil belajar siswa. Maka aspek-aspek penilaian efektivitas suatu produk perangkat pembelajaran adalah sebagai berikut.

Tabel 1. Aspek-aspek Efektivitas Pembelajaran

\begin{tabular}{l|l|l|l}
\hline No. & $\begin{array}{c}\text { Aspek yang } \\
\text { Dinilai }\end{array}$ & $\begin{array}{c}\text { Metode } \\
\text { Pengumpulan } \\
\text { Data }\end{array}$ & \multicolumn{1}{|c}{ Instrumen } \\
\hline 1. & Hasil belajar & Pemberian tes & $\begin{array}{l}\text { Tes unjuk } \\
\text { kerja }\end{array}$ \\
\hline 2. & Aktivitas siswa & observasi & $\begin{array}{l}\text { Lembar } \\
\text { observasi } \\
\end{array}$ \\
& & & aktivitas \\
& & & siswa \\
\hline
\end{tabular}

PEMBAHASAN

Hasil Efektivitas Perangkat

Pembelajaran

Hasil belajar siswa diukur dengan penilaian terhadap keterampilan menulis resensi siswa. Pengukuran tes tersebut dilakukan berdasarkan indikator penilaian menulis resensi yang telah divalidasi oleh ahli. Indikator penilaian dalam menulis resensi tersebut antara lain adalah identitas novel, kelebihan dan kekurangan novel, ikhtisar novel, struktur kalimat, dan ejaan.

\section{Gambar 1. Diagram Ketercapaian Indikator Menulis Resensi}

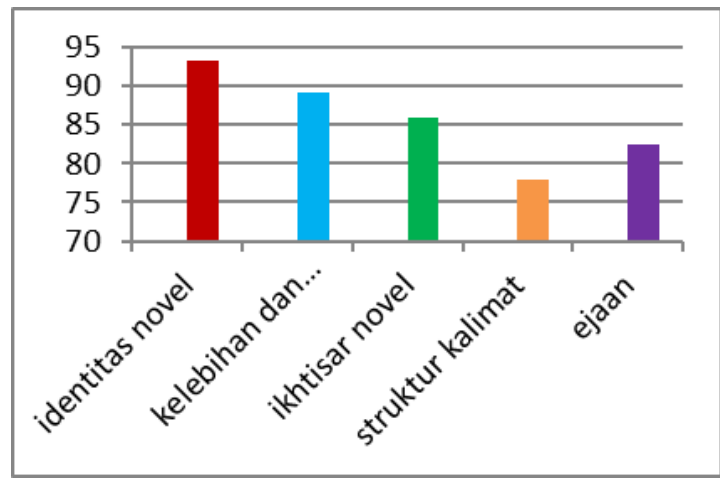

Dari hasil belajar siswa tersebut, dapat dilihat bahwa ketercapaian yang paling tinggi adalah pada aspek identitas novel dengan angka 93\%. Sementara aspek yang paling rendah ketercapaiannya adalah aspek kebahasaan yaitu struktur kalimat. Pada aspek ini siswa hanya mencapai angka $78 \%$ untuk ketercapaian. 
Berdasarkan analisis terhadap hasil menulis resensi siswa yang menjadi subjek penelitian, maka terdapat temuan antara lain; Pertama, siswa yang memiliki kualifikasi nilai sempurna (S) berjumlah 3 orang. Siswa yang memiliki nilai dengan kualifikasi baik sekali (SB) berjumlah 16 orang. Siswa yang memiliki nilai dengan kualifikasi baik (B) berjumlah 12 orang. Siswa yang memiliki nilai dengan kualifikasi lebih dari cukup (LC) berjumlah 2 orang.

Kedua, terdapat siswa yang tidak tuntas sebanyak 2 orang dengan kualifikasi nilai lebih dari cukup. Dengan demikian, dapat dikatakan presentase siswa yang tuntas adalah 93,94\% dan persentase siswa yang tidak tuntas adalah 6,06\%. Ketiga, berdasarkan nilai ratarata yang diperoleh secara klasikal, dapat dikatakan bahwa kelas yang menjadi subjek penelitian telah tuntas secara klasikal walaupun masih terdapat 2 orang yang belum tuntas. Hal ini dapat dilihat dari rata-rata kelas 85,51 yang berada pada kualifikasi baik (B)

Hasil aktivitas siswa dalam pembelajaran menulis resensi tersebut dapat dilihat pada diagram berikut.

Tabel 2. Kumulatif Altivitas Siswa dalam Pembelajaran

Menulis Resensi

\begin{tabular}{l|l|l}
\hline \multicolumn{1}{c|}{ pertemuan } & $\begin{array}{r}\text { Persentase } \\
\text { Aktivitas }\end{array}$ & \multicolumn{1}{|c}{ Kriteria } \\
\hline Pertama & 85,71 & Sangat tinggi \\
\hline Kedua & 66,67 & Tinggi \\
\hline Rata-rata & 76,19 & Sangat tinggi \\
\hline
\end{tabular}

Berdasarkan tabel tersebut, dapat disimpulkan bahwa persentase aktivitas siswa pada pertemuan I secara keseluruhan sebesar 85,71 dengan kategori sangat tinggi. Kegiatan yang diamati adalah menyimak dan memperhatikan instruksi dari guru, menjawab pertanyaan guru, berdiskusi dengan guru dan teman dalam memperdalam konsep menulis resensi, mengemukakan pendapat tentang resensi, dan mengerjakan latihan yang mendukung materi menulis resensi. Dengan demikian, dapat disimpulkan bahwa perangkat pembelajaran berbasis pendekatan kontekstual dapat membangkitkan aktivitas siswa dalam pertemuan I. 
Pertemuan II merupakan kegiatan pembelajaran presentase hasil menulis resensi siswa. Jadi, aktivitas yang diamati hanyalah aktivitas lisan yaitu bertanya, menjawab pertanyaan dan mengemukakan pendapat atau sanggahan. Dari data tersebut dapat disimpulkan bahwa presentase aktivitas siswa pada pertemuan II secara keseluruhan sebesar $66,67 \%$ dengan kategori tinggi.

\section{Gambar 2. Diagram Aktivitas Siswa dalam Pembelajaran \\ Menulis Resensi}

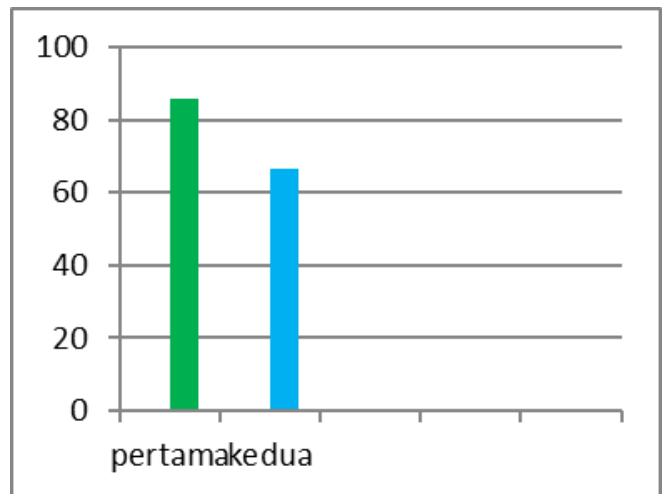

Dengan mengamati hasil dari dua pertemuan tersebut, dapat disimpulkan bahwa aktivitas siswa tergolong sangat tinggi dengan rata-rata presentase 76,19\%. Maka, perangkat pembelajaran berbasis pendekatan kontekstual dapat menumbuhkan aktivitas siswa yang tinggi dalam pembelajaran.

\section{PENUTUP}

1. Berdasarkan hasil penilaian menulis resensi yang ditulis oleh siswa, kelas yang menjadi subjek penelitian ini dinyatakan tuntas. Hal tersebut terlihat dari rata-rata yang diperoleh siswa pada kualifikasi baik (B) yakni 85,51.

2. Hasil analisis aktivitas siswa yang telah dikumulatifkan oleh pengamat menunjukkan tingkat aktivitas siswa selama pembelajaran. Dengan mengamati hasil dari dua pertemuan tersebut dapat disimpulkan bahwa aktivitas siswa tergolong sangat tinggi dengan rata-rata persentase 76,19 . 


\section{DAFTAR PUSTAKA}

Aleka \& H. Achmad. 2010. Bahasa Indonesia untuk Perguruan Tinggi. Jakarta: Kencana Prenada Group.

Badariah. 2010. Pengembangan Perangkat Pembelajaran Kimia SMA Berorientasi Pendekatan CTL. Tesis: Uniersitas Negeri Padang.

Fauzan, A. 2002. Laporan Penelitian Hibah Bersaing XII/Perguruan Tinggi. Padang: UNP.

Johnson, Elaine B. 2007. Contextual Teaching and Learning: Menjadikan Kegiatan Belajar dan Mengajar Mengasyikkan dan Bermakna. Bandung: MLC.

Nurhadi. 2004. Bagaimana Meningkatkan Kemampuan Membaca? Bandung: Sinar Baru Algesindo.

Rahardi, Kunjana R. 2009. Bahasa Indonesia untuk Perguruan Tinggi. Jakarta: Erlangga.

Ramadansyah. 2010. Paham dan Terampil Berbahasa dan Bersastra Indonesia. Bandung: Dian Aksara Press.

Rohman, Muhammad dan Sofan Amri. 2013. Strategi dan Desain Pengembangan Sistem Pembelajaran. Jakarta: Prestasi Pustakaraya.

Trianto. 2009. Mendesain Model Pembelajaran Inovatif-Progresif: Konsep, Landasan, dan Implementasinya pada Kurikulum Tingkat Satuan Pendidikan (KTSP). Jakarta: Kencana Prenada Media Group.

Trianto. 2012. Model Pembelajaran Terpadu: Konsep, Strategi, dan Implementasinya dalam Kurikulum Tingkat Satuan Pendidikan (KTSP). Jakarta: Bumi Aksara.

Yolanda, Nela Sari. 2010. Pengembangan Media Pembelajaran Matematika Berbentuk Komik Berbasis CTL pada Materi Bangun Datar di Kelas III Sekolah Dasar. Tesis: 
